\title{
Teaching through Alternative Methodology
}

\author{
Sonila Tatili
}

\begin{abstract}
The rapid development of information and communication technology has a significant impact in the teaching process. This happens because of the existence of the advantages that this sphere entails in the pedagogical practices and methods. As such, they are briefly brought to us : easy access to information; increasing interest in learning; more ability to embed it into memory and preserved in the knowledge gained as a result of the inclusion of visual memory improvement; interactive teaching as well as easy exchange of knowledge, etc. With the aim of identifying the advantages that the technology incorporates in the teaching process of methodology, this paper aims to highlight the role of technology in the teaching and learning process of English, the achievement of the student in the learning objectives and how the technology of information and communication is intertwined in education. The study's research is about determining what impact technology has in the teaching process, meanwhile the supporting questions raise questions about the advantages of teaching technology as well as the impact on the level of learning of Albanian students. Study hypotheses, which are expected to be proven to be sustainable or not, are: Technology brings quality-enhancing teaching of English; efficient use of ICT enhances student learning. The study methodology is based on the combination of theoretical and empirical analysis, according to the case study.
\end{abstract}

Keywords:Teaching process, technology, information and communication technology, learning, education, multimedia, skills.

\section{Introduction}

\section{Research paper vindication.}

Information technology and communication as a case study in the education nowadays. The processes of political, economical and social globalization implicit new initiatives which aim together societies in a smaller world and solve problems and connect easier. The school is considered as a social institution so to help new generations better in order to develop psychophysical overviews for the individual as in important actor in the society. The society of the future never stops and never gets satisfied with the present but it is always in search of the best aiming to make the school a place where students can get wisdom but at the same time education. The future of the humankind is more over depending on the development of the education culture, science and technology from which all the contemporary societies make positive changes for a better future in educating generations. Nowadays we randomly listen about new concepts such as technology, competences, strategies, new lesson plan, innovation but the problem is that teachers are not finding the right way how to adopt these concepts in the classroom. The classroom is considered as a sacred place but also an important mean of helping individuals to face every life existing dilemmas which is considered one of the most problematic situation in education nowadays is that teachers do not know enough the functions and the importance of ICT in the teaching and learning process especially in the pedagogical aspect. The changes that are happening in education make us the teachers, to have a different view of the interior reorganization of the lesson structure but also teachers are always aware of the fact that these changes affect the exterior structure of the education considering the individual's behavior in education activities. This means "every change in education before and after being planned, means an essential study of the existing situation and the factors which limit a specific change". (Osmani 2010) Studying the situation this is a condition for a successful change in order to make a better system of education and also helping individuals to be not only professionals. The inclusion of ICT in teaching and learning process is a very important step especially on education reform system. This inclusion means not only exactness but also preparations by professionals so this innovative issue may be successful. The innovative concepts in education are introduces the last ten years but they were not well-oriented so to swipe up from the old system of education to improve teaching tools, to enhance new methodology, to use contemporary strategies in order to know 
better the interest of the students. It is very important to know the interest of the students in order to plan, organize and succeed in the teaching process. The inclusion of ICT in the Albanian context is considered as a positive phenomenon from the experts teachers, students, parents but it is existing a serious problem in proving that the student knowledge are more stable and as a result of this the performance of the students should be more satisfied. At the same time, there is a serious problem by the part of the teacher to adapt ICT in teaching process. There are some difficulties in adapting ICT for the different reasons. Teachers should find and get improved in finding the right path so to include means of ICT to introduce a mirror of this situation in Albania and to prove all the above issues, this scientific study based on hypothesis, ICT in teaching influence that the knowledge taken in school are more stable and facilitate the work of the teachers. For a school to be contemporary it is necessary to find new approaches in teaching, by starting from the methods, textbooks,trainings for the teachers so to adopt the ICT in the learning process. The main objective is to advance ICT and include it in today's education: ICT nowadays has given a new dimension to the teaching and learning process of the foreign languages. The new generation of the students are undergoing with their will to this new era of education. This is seen also as a force giving methodology by the Ministry of Education but not only. At the same time teachers are finding difficulties in perception this new element in the teaching process, despite the fact that the students welcome ICT with such a big pleasure. This research also enforces the use of ICT especially in the foreign languages classes. We will treat the integration of ICT and the professionalism of the teachers using this last concept, but at the same time giving theoretical, methodological and institutional aspects of interactive teaching and learning. The adaption and use of ICT in the learning and teaching process in the high schools in Elbasan. There is no doubt that there are many difficulties that the teachers are facing in using ICT in the classrooms, starting from the missing of the infrastructure, lack internet connections, the non professional teachers, and at the same time the judgment that the mentality enhances.

Many of the professionals, are of the opinion that the main objective of ICT is to adopt new interactive techniques and strategies at schools which reinforce critical thinking, motivate and easily helps the process of learning a second foreign language .But, in the Albanian context these innovative practices don't have the right importance and are given an easy shot to make it clear.

\section{Theories supporting this research thesis:}

Some of the authors have given their professional overview and their theories in ICT integration and use in the classroom , by forcing the idea that the use and integration of ICT means not only to put them in the class and make a new structural lesson plan(Bray, 1999:14), and to integrate it twice a week , and not only to use it by ICT means(Dockstader,1999:73) and to fasten this process with the ICT integration, (Bailey, 1998:57), but it very important to know how to adopt them in the right manner sot to have a successful teaching and learning process.(bailey, 1998:62). To my opinion, ICT must be in function of the learning process, but we should find the most professional clothe of the ICT usage and integration.

Some of the authors are of the thought that the ICT integration is a didactical means of teaching, concerning the interactive and constructivist attitude. According to some of the authors Larose and Lafrance "The teachers support a constructivist and a socio-constructivist attitude, which means that if teachers know how to use ICT means and learning how to transmit them to the students in class, everything will be successful and we will have a better contemporary system of teaching and learning a foreign language process"(Larose F; Grenon V and Lafrance S, 2002:27) Educational experts consider learning as an active process that leads to knowledge acquisition, which is long-term and sustainable, measurable and specific to behavioral change (OECD, 2007). The primary function of learning is to encourage individuals to develop skills to solve a problem, as well as to sharpen reasoning as a critical and creative thinker. Learning also helps to develop an individual's self-awareness and awareness of his or her environment. The purpose of the teaching process by ICT is to make learning possible. However, while the purpose of the

There are many theories aimed at supporting the ICT learning and teaching process. Thus, for example, Paivios' theory on dual coding (established in 1986) states that visual and image codes that represent information are used to organize incoming information and to convert them in which knowledge can be taken, stored data, and retrieved for later use. The emphasis on the importance of memory has evolved into broad imaging applications, aimed at accelerating the process of acquiring knowledge. A foreign language has always been involved in this process, but it was explicitly included as an educational partner when images began systematically to take shape as a picture. However, memory remains a decisive actor, because it is the basis of all knowledge and thoughts. The importance of memory is argued and dealt with more widely, because learning and memory are at the core of educational objectives. In particular, an important element for the dual coding theory and its applications are useful effects in recalling concreteness and images (Paivio, 2006, chapter 4): 
Learning process means a good state of mind and memory is a very important part in fixing the new information and to achieve this one of the best ways in by concrete experiences and practical tools.. Concerning concreteness, memory performance generally grows uniformly from abstract words (eg. truth, justice etc.), with concrete words (eg. chair, man), for objects (or their images). In the case of language, the effect of concreteness occurs with materials ranging in length from words to sentences, to long passages, to concrete memory, exceeding the abstract memory work with an average ratio of 2: 1 . The advantage of concreteness is even more striking in the tasks related to the memory, in which the behavior in the mind of the response elements is caused by the concrete words of stimulation or the pictures. (Paivio A., 2006)

Severin's theory (1967) emphasizes that learning has grown as the number of available stimuli has increased (Severin, W. J. \& Tankard, J. W., 2000). The incentives supplied through different channels should be relevant to each other; otherwise it would lead to a decline rather than an increase in learning and knowledge consolidation (Kaur S., Rose HJ, Lazar R., Liang K. \&Metherate R., 2005).In 1974, scholars Baddeley and Hitch, in their quest to describe an accurate pattern of shortterm memory, laid the foundations of active memory theory. This theory suggested a model consisting of three main components: the central executive, the phonological sketch, and the visual space designer (Baddeley A. \& Hitch G., 1974).

In 2000, in the studies on active memory theory, Baddeley added a fourth component of the previous model: episodic buffer (Baddeley, 2000). Concretely, today the components of the model of active memory theory, as presented in the scheme of this model, are :a) the central executive, which acts as a supervisory system, and controls the flow of information from and toward its subordinate systems, which are short-term custodians dedicated to a content domain, such as, for example, verbal and visual spatial ;b) Phonological illumination, related to language articulation, preserves the verbal content of vocal and sub vocal repetitions; c) Visual space plotter serves for visual space data, which consists of visual memory; d) episodic buffer, subordinate subsystem, which by its own name determines, supposed to hold integrated episodes or shreds in a multidimensional code. By doing so, this element / component act as a buffers, not only among active memory components, but also connects active memory with perceptions and long-lasting memory. (Baddeley A., 2012)

Sweller's theory of cognitive load (1988) refers to the total amount of mental effort used in active memory within the workload of active memory work while solving problems, thinking and reasoning (including perception, memory, language, etc.). Sweller argued that teaching designs can be used to reduce cognitive load among students (Sweller, 1988). The theory of cognitive load differentiates the cognitive burden into three types: perceived, foreign, and closely related specifically :a) Conjunctive internal load, perceived, is the effort associated with a particular subject ;b) Foreign Cognitive Charge refers to how information or tasks are presented to a student;c) Conjecturally related load refers to the work carried out in the creation of a permanent scheme or permanent preservation sector. (Kaur et al.,2005).

\section{Hypothesis and research questions.}

\section{H 1: ICT helps and facilitates the teaching and learning process of English language!}

\section{H 2:Teachers of English need supports and qualification in order to be professional in integrating ICT in the process of teaching English.}

Research questions that support this study are:

Which is the situation of the physical classes concerning the ICT means?

If this infrastructure of the classrooms is satisfying, can teachers make them functional

Are the teachers of English enabled to use the means of ICT and do they know how to adopt and integrate them in the English teaching processes?

How do the teachers feel about the integration of the technology in education'?

Are the teacher trained enough to use the ICT in the classroom?

Does ICT facilitate the learning process of the English language?

Does Albania have the proper infrastructure to use ICT?

The problematic clarification of the topic. 
This ICT introduction in the classroom and its thematic aspect, are innovative issues through which this study will improve and enhance, motivates and stimulates teachers to respect the past situation in Albanian education but their main objective is to make a better over view in enriching teaching with techniques methods and shapes designing new teaching results, this means enrollment of the learning process. This study is concentrated in the integration and usage of new ICT techniques of teaching and learning foreign languages, English in this case, seen in some dimensions in the Albanian context. English teachers face many difficulties in adopting new means of technology. The science and new rules are coming faster than thought. And this situation is not as easy as for the teachers to be competent in practicing all the teaching techniques based on innovation. But studies all over the world on this field have shown that the socio-cultural and the economic-political context influence a lot in the integration of ICT in the teaching and learning a foreign language. But in our context, in Albania the integration of innovative means of teaching and learning a new foreign language has problematic issues. Some of the problems are:a. the lack of the teachers' trainings, b.the innovative equipments,c.the scale of using ICT in the classrooms in the process of teaching and learning.

These are serious problems concerning the usage of ICT in Albanian classes, and for the above problems, there is a deep study of the actual situation in the classes and also it was needed a research study, based on interviews and experiments. it was very important to get a clear mirror of the scale of the acknowledgements by the part of teachers and students and to extinguish the problematic barriers which lack the process of using ICT. From what was seen in general and in specific situation was that the ICT usage and terminology was seen only in theory but in practice there were things unclear to them. What was of a great importance was to know the disposal of the teachers to accept the new methods and techniques so to get involved in the alternative methodology of teaching. But what was of the biggest interest was the fact that they were not ready to use these new ICT tools because of the mentality existing in Albanian system of education. To this point what was the strongest point of the study was to discover how much and how many times ICT tools used were.

The term "information technology and communication "it is usedto include a series of services and applications referring to some tools which function to enhance and facilitate a specific process through webs and telecommunication. Referring to Gerbault (2002:13) ICT is referred as " a unit of the most development technologies to treat and modify the information in a synchronically way through voice,figure, or animated images and text. In a world divided by clashes of cultures and beliefs, the potential ofthe new media for fostering intercultural understanding and exchange is enormous. In the history of mankind, access to information and knowledge has never been so straightforward at a local, regional, national, or global level. Judicious deployment of ICTs can encourage and sustain cultural and linguistic diversity in individuals and in society in general. Facilitating access to other cultures and languages is the chief goal of the language teaching profession, and using ICT resources effectively in their teaching represents one of the chief challenges facing language teachers today In their contribution to this study (Modeling a Field-Based Internet Resource for Modem Foreign Language Learning: the Case of RussNet), Dan E. Davidson and Maria D. Lekic demonstrate the potential of ICT-driven language learning, highlighting the flexibility of the media available.

According to Chris Abbott $(1998 ; 197)$ the ICT is considered as a " set of numerical technologies, which are based on the usage of the computer with the only objective, so to spread the information and to maximize the effect and impact of the communication" There is also an Albanian contribution on the "standard of the ICT teachers standards which in fact clarify the usage of these in the system of education in Albania. ICT is considered as the set of the electronic devices to collect, work with and also to represent the information gicen to the users so to facilitate their work .

As far as we see and read about the ICT we come to the conclusion that this is a set of electronic devices and means to transmit the information wanted. ICT in education is used in order to manipulate and also to attract the attention of the students so to make a more interesting class, but at the same time it facilitates the work of the teacher not only to be a better performer in the class but also to help him / her to make and practice a contemporary methodology viewed from the didactical point of view.

Models of using ICT in the class.

The Moersch model $(1995,2001-22)$ insists that there are seven levels of which a teacher should pass in order to integrate the ICT in the class.

Zero model, represents the non use of the ICT in the class for different reasons. This may happen for different reasons such as the non access of the internet or any other different problems. 
The sensibilisation means the phase in which the teacher is in contact indirectly with the means of integration of ICT.

The exploration is the phase when the teacher uses ICT to search extra information in order to solve the problems in the lesson process.

The infusion is the phase where the teacher uses the ICT means in order to support the pedagogical activities, in order to reach the decision taking. For example the teacher may use the ICT means in order to illustrate any problematic issue in the class, for the students to get better the ideas in the class to connect the theory and the practice.

The integration means the use if the ICT means in order to identify the real problem solving connected to a real situation problem.

Expansion means that the teacher interconnects with the people outside the institution where he or she works in order to reach the pedagogical objectives.

Perfection. In this stage the teacher makes the student be the main protagonist of the lesson class. The student is the one who checks for the information he wants to use in the lesson. In the case of the English learning, the students decides what information to search for. For eg. In the case of the Present Simple learning , the students in order to learn in better and faster, searches for a text, such as a fairy tale or a song text with lyrics in present simple. He is not obliged to learn it in the textbook during the class.

There exist another model which explains the phases of the ICT integration in the lesson class. This model takes the name from the person who invented it as useful to be known by the teachers in order to get accomplished with this integration. It is called the Morais model. This model includes two phases.

The first stage is called the "starting point"and it is divided in two other subphases "compatibility and the "the practicum. In the first, the teaher should be very attentive in order to see what is the perfect strategy to use in order that the lesson is student-centered. The second one deals with the teacher, because he is the one who tries to use the ICT means for two reasons. The first is connected with the personal usage of ICT in order to adopt the method used in he class. The teacher also decides what to use in the class in order to reach the specific objectives. The second one it is on the teacher to decide what material to choose for the specific class and theme, and if it the right means for the class to be used.

By bringing these two models we come to the conclusion that the teacher who is motivated to use ICT in the English teaching process, should be very professional in following the right steps. This is what is lacked in our Albanian context in the system of education. Teachers are misleaded and confused because they do not follow the steps needed. What teachers have to do is to start from the personal conscience to use ICT for "personal usage" and then to use some of these means by following the way of the "professional usage "and to reach in the "professional usage" only in this manner , the teachers are going to be professional and didactical.

\subsection{What are the methods of teaching?}

Teaching methods and techniques are standard procedures that teachers use in collaboration with students to present and develop materials and learning activities to achieve learning goals and objectives. Teaching methods are divided into two large groups: the methodology that teachers and learners have in mind. In the last decades of the last century, priority has been given to the skills that give priority to the student's activity. This trend has begun to be felt even in Albanian schools.

Methods centered on the teacher aim to provide information that will provide the basis for developing further thinking. This group includes: explanation, lecture, conversation, deploring, questioning. The student-centered approaches aim at meeting the learning goals and objectives by actively enabling the learner. These methods are divided into two subgroups: group work methods and research methods.

Because of the characteristics of the class group, some of the most successful methods and techniques are those that relate to group work. These techniques influence the student's higher activation in the learning process, changing attitudes and ideas. These techniques increase the effectiveness of teaching, as learning outcomes are high. This subgroup includes discussion, debate.Research methods have as main characteristic, information exploration and conclusions drawn by students themselves. This subgroup includes: research project, survey, excursion. To use the methods successfully, the 
teacher should know well their characteristics, methodical progress, select them in accordance with the subject they develop and the student's particulars. One of them should not be overstated, but should be used in combination.

Learning methods are ways, ways, steps, and didactic processes that use the teacher's teachers in the process of teaching and learning abroad for the transmission and acquisition of knowledge, skills and habits. Historically, they have changed, been perfected and modemized in relation to the transformations of the society, with the intentions and interests that it has presented to the school at different times, as well as with the specific changes of the school itself, of various sciences: psychology, pedagogy and sciences the other.Teaching methods are conditioned by the content of the lesson, but also by the forms used in the organization of the learning process.

The teacher directs the work of the groups in such a way that they all become active and express their opinions. In order for the activity not to go out of control, the teacher should provide clear instructions for each step of the activity. Working in groups requires students to communicate, discuss, analyze ideas, develop their thoughts through conversation. Working with groups improves students' ability to think, creating opportunities to raise hypotheses, verify and analyze them.

Working in groups is organized in 3 stages.

Phase One: This is the "silent" phase, no pupil suggests to a friend what he should do. In this way, the respect for the companion's work, as well as the responsibility of each in front of the group's friends, is nurtured.

Second Phase: Students of each group chat together, make corrections, give arguments, and eventually decide on the final decision they post on the chart as their group work. During this phase, setting some rules is indispensable. Pupils should respect each other. They should listen carefully to the companion's arguments to provide convincing and compelling arguments. In working with groups, students feel the need for communication with courtesy, with no impunity and respect. In the sense that responsibility is solved by group members, relationships of optimism are created in the organization. In this way, the group turns into a miniature of an effective organization.

Third Stage: The affairs of the groups posted on the blackboard are subject to group review. The teacher chooses a student of any group to respond to the remarks of other groups. Students ask questions to other classmates. The climate of debate and exchange of arguments is more hot. In these two phases each student has the moral responsibility for the proficiency representation of the work of the group he has participated.

Organizing group activities brings a variety of benefits to the student's teacher. The student is more likely to communicate with each other. Pupils are more focused on learning because each has its own task and responsibility, from which to determine and the outcome of the group. Pupils feel cheaper and safer than when asked before the whole class. Increases the amount of time each student has to speak. Working in groups helps the student to shy away from expressing thoughts. Students with difficulty feel better, they ask more freely about a friend than a teacher, cooperate with them, follow them with interest and feel less of their mistakes.

Working with groups is organized so that students interact with each other. Groups are formed with four to seven students, where they have the opportunity to exchange views and express ideas, communicate freely and discuss. Groups can also be formed according to the preferences of the audience. Groups are usually heterogeneous, so they have learned.

The teacher must adapt the method that is more efficient for one lesson. Each of the methods has its own benefits and shortcomings. Of course the more knowledge the teacher has, the more skilled will be to make decisions about any situation that is created in the classroom.

These sampling actors helped me a lot to do my research, and at the beginning there are given all the characteristics of the subjects taken in the research, a study which was held during 2015-2017. Then every result is given in tables and graphics by respective comment.

In the city of Elbasan there 16 high schools, and in every school it is taught English, even in rural areas there are 18 high schools, and English is taught in all of them. In some schools, English is taught as a first foreign language , while in other it is taught as a second foreign languages. 


\begin{tabular}{|c|c|c|c|c|c|c|}
\hline School & $\begin{array}{l}\text { Students of } \\
\text { English in the } \\
\text { class X }\end{array}$ & $\begin{array}{l}\text { Students of } \\
\text { English in the } \\
\text { class XI }\end{array}$ & $\begin{array}{l}\text { Students of } \\
\text { English class } \\
\text { XII }\end{array}$ & $\begin{array}{l}\text { Teachers of } \\
\text { English }\end{array}$ & $\begin{array}{l}\text { Participants in } \\
\text { the interview }\end{array}$ & $\begin{array}{l}\text { Active } \\
\text { participants }\end{array}$ \\
\hline A & 140 & 109 & 87 & 2 & 23 & 100 \\
\hline$B$ & 111 & 98 & 74 & 2 & 14 & 68 \\
\hline C & 130 & 88 & 91 & 2 & 13 & 88 \\
\hline D & 145 & 121 & 116 & 2 & 23 & 44 \\
\hline
\end{tabular}

Table 1. The characteristics of the first four schools.

All the participants of the first four schools were very curious to participate in the interviews which held not more than ten minutes per each student. We do not exclude the fact that they were embarrassed in front of the interviewer but with the passing of the seconds they became more active and eager to give real answers to the respective questions.

What was worthy to be mentioned, are the schools characteristic connected to the ICT.

$\begin{array}{lcccl}\text { School } & \text { Labs } & \text { Computers in the lab } & \text { Internet connection } & \begin{array}{l}\text { Other devices/means of } \\ \text { ICT }\end{array} \\ \text { A } & 2 & 22 & \text { YES } & \begin{array}{l}\text { Video- } \\ \text { projector,CDs;DVDs,TV } \\ \text { etc } \\ \text { Video- } \\ \text { projector,CDs;DVDs,TV } \\ \text { etc }\end{array} \\ \text { B } & 1 & \text { YES } & \begin{array}{l}\text { Video- } \\ \text { projector,CDs;DVDs,TV } \\ \text { etc } \\ \text { Video- } \\ \text { projector,CDs;DVDs,TV } \\ \text { etc }\end{array} \\ & 1 & & \text { YES } & \end{array}$

Tab.2. Schools situation concerning ICT.

As far as these schools are considered as experimental schools, and four of the best schools in the city, where also the government funds every year to improve their performances, even the real infrastructure is very good, and in excellent conditions.

$\begin{array}{ll}\text { Teachers of English } & \text { Number of qualifications } \\ \text { T1 } & 2 \\ \text { T2 } & 3 \\ \text { T3 } & 2 \\ \text { T4 } & \text { No } \\ \text { T5 } & 2 \\ \text { T6 } & 3 \\ \text { T7 } & 1 \\ \text { T8 } & \text { No }\end{array}$

Tab.4. Concerning the qualification of the teachers.

Students poll results 
Question no. 5:Do you know about ICT? YES/NO

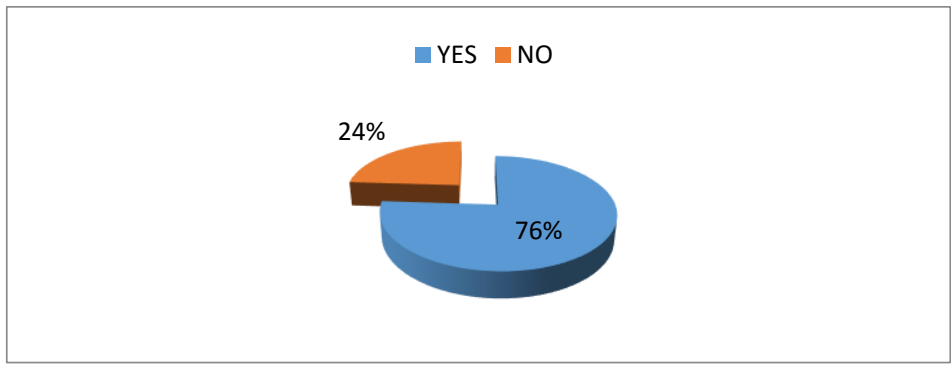

\section{Graphic 1. The students acknowledgement of ICT}

This is a very important starting point to the research. The recognition of the term ICT and everything includes is crucial. Even in the didactic terms, the process of understanding the unknown has a very important effect on what is going to be learnt. According to these questions, the majority of the students were aware of this term, because their daily life nowadays is surrounded from the computer and what it contains. Despite the main objective they use the ICT means, which is in fact to use the social media webs (facebook, instagram, twitter , snapchats), they also used the means of ICT in order to send emails to the teachers and to build a communicative area with mates and the teachers. $76 \%$ of the students are a very high percentage in fact, which is satisfying in order that the class functions. The other part which is $24 \%$ had never heard of ICT, even though they were in touch with its means every day.

Question no. 6:Do you use computers in your school? YES/NO

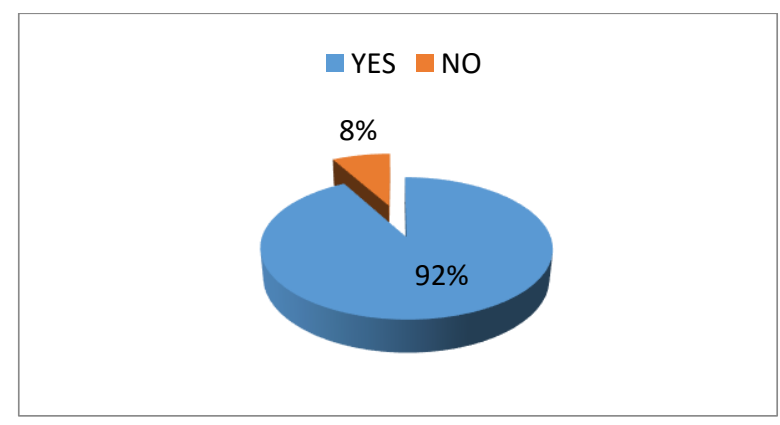

Graphic. 2. The use in percentage of ICT from the students.

This answer consists in knowing if the students use the computers or not. It is not awkward that there are still students who cannot use the computers. And in fact $8 \%$ of the students taken in the interview didn't know how to command the mouse and to navigate in the computer. They added that some of them had never used the computer because they didn't know it or they were not interested to. But, the majority of the students as shown In percentage, $92 \%$ of them were good users. We cannot pretend to use ICT if they don't know to use a computer, and how could they navigate and use it for pedagogical aims. 
Question no. 7: How many times do you use them? (times/week)

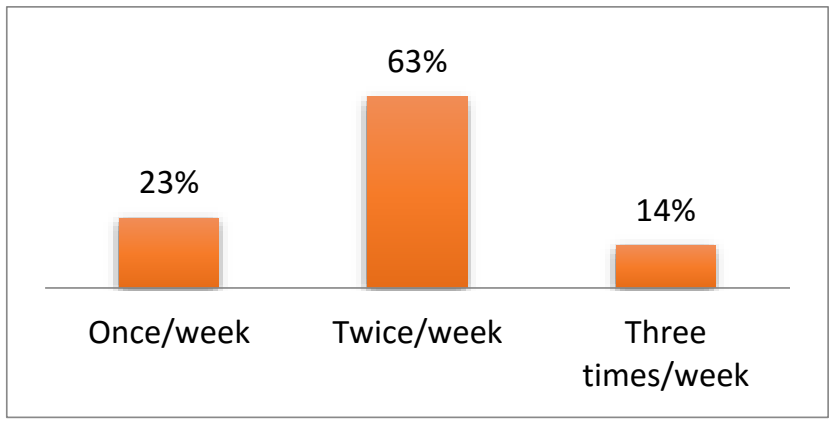

Graphic 3. The frequency of usage of ICT.

As far as in the curricula of the high schools, English classes are developed three times a week, my interest was to discover the frequency of the usage per week. This question in fact was very curious because that depended on the level of the class. $23 \%$ of the students taken in the interview answered that they were included in lessons based on ICT once a week, especially in the listening section. The other $63 \%$ were included in individual work at home to enlarge the information through short stories, movies and songs on the radio in order to practice home their skills in English. This was very interesting because it shows interest by the students. The other $14 \%$ used in three times a week so to make the homework during the Google Classroom. One of the teachers used the new innovative class when the students were home, as an extra homework so to be in contact with the language.

Question no. 8:Do you have internet access?

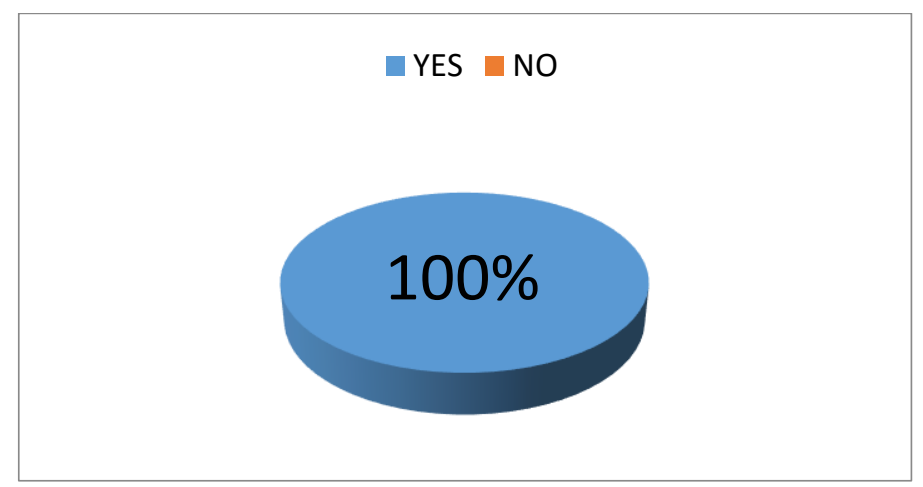

Graphic 4. The internet access in school.

The internet access in the school was always in connection and with a goof speed. This is due to the latest politics made in education, for the administrative cohesion of the school and the performance of the head of the school in order to report everything happened in the school. But also, due to the necessity that the schools had in having labs, the internet was always present. We can't take in consideration the fact that once in the time, it was a disconnection for some minutes, but in general the students were satisfied.

Question no. 9: For what reason do you use the computers?

Lesson aims, Social Media, Games, To learn English 


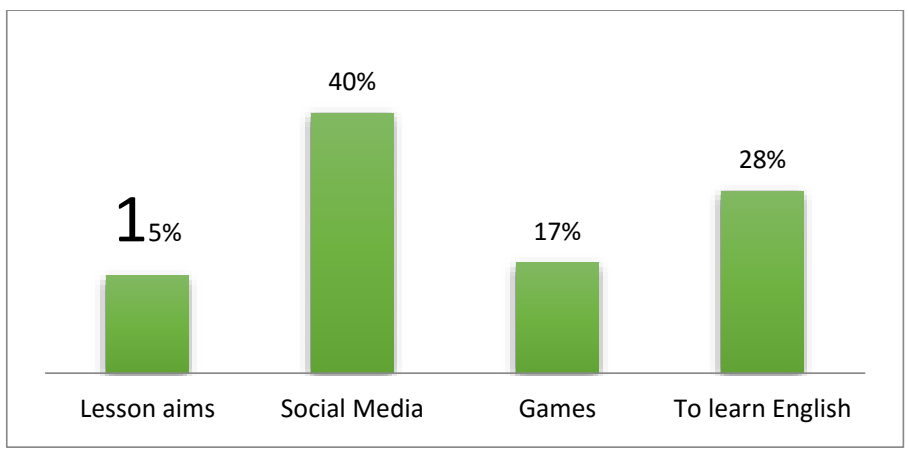

\section{Graphic 5. Reasons of using ICT in the class}

The usage of the computers by the students was taken in general in order to see in what extend they used the computers in the labs and at home. $15 \%$ of the students told that used the computers in order to find the extra information for every project works, essay or any other kind of homework. Even when they wanted to learn more about the daily topic taken they navigate and selected a movie, a song, a short story, a documentary. $40 \%$ of them, proved the daily problematic issues that teachers and parents have recently; the time that students spend on the internet and in front of the computers or in the other cloned device , laptop(lap ---top, made for comfort, a device the same as the computer which could be handled on the top of the lap, for comfort). This group of people used these in order to chat or to review in their accounts created on the internet for massive communication objectives. Games was another aim of usage, the majority of the students using computers for gaming were boys. They also told that they could spend hours in gaming. The most satisfying answers belonged to the main aim of this research: To learn English! With or without the assignment homework by the teachers, they individually used the computers by downloading programs in order to learn English. These students were aware of the fact that English is a language that they couldn't do without.

\subsection{Conclusions.}

In this chapter there are mirrored all the conclusion taken from the study in order to answer to the research question and to verify the hypothesis. During the research ICT has an important role in our system of education even the Albanian context lacks a lot of things. Teaching English nowadays in Albanian classes has been facilitated by the integration of ICT. The responsibility is held by the teachers of English. In this study was highlighted the definition and the understanding of the ICT in education. In the literature review many author were consulted in order to explain the definition and the impact that ICT has in education. ICT is the set of different media used in order to spread the information. Some of the means used are the computer, video projector, CD, DVD, interactive board. At the same time it was discussed the impact that they have in the class for example: raise of motivation, interaction, critical thinking and successful output.

There were identified the factors affecting the didactics usage of ICT interfering in its performance such as personal, cognitive, institutional, pedagogical factors. There were many models presented in order to make the teachers be aware of the functions and positive effects of ICT integration. The first objective was to see the physical infrastructure of the actual situation of ICT in Albanian classes. In fact during this research what was seen is the absence of the computers and other means but not only the internet connection was slow. The internet access was missing in the majority of cases. These made the students to be not .motivated and the teachers too. The missing of the infrastructure and the lack of the internet access in school are the two biggest obstacles in affecting the integration of ICT in the class.

Secondly, in the literature review was seen that there are a limited number of researchers on this topic especially on the relation that ICT has with foreign languages, English in this case. Meanwhile the first thing to be seen was the disposal of the teachers to welcome the ICT. All the teachers should be aware of the fact that integrating this new era of education can facilitate their job by having positive results. On the other hand, it should be accepted that this process is difficult and still in progress affected by external stimuli such as cultural, psychological, didactics factors, making it complex.

Thirdly, in this research it was made a clear establishment of the role of the teacher as a result of the integration of ICT. On one hand, we should have a teacher who is prepared, trained, qualified and ready to adapt the changes because the role 
of the teacher in this aspect is very important. Teaching means science and art. It is science because the teacher transmits scientific information to the auditor but it is an art because of some features that an alternative teacher should possess. Teaching process through ICT as a part of contemporary methodology means that the role of the teacher is not only being a facilitator but also a connection means, good manager. In the traditional class the work is based on textbooks and blackboard while in alternative classes the teacher goes from the unit to the global and this means a virtual world within the class by using ICT mechanism but before doing this the duty of the teacher it to welcome the integration of ICT, get use do it, be qualified, become an expert and them put them in practice.

\section{Bibliography}

[1] Arabski,J. \& Wojtaszek, Adam. 'Aspects of culture in Second Language Acquistion and Foreing Language Learning'Springer (2011:29)

[2] Bortini,P \& Motamed-Afshari, Afshari,B. 'Intercultural Competence Research Report' Developed and demonstrated within the framework of Youth in Action: Released 16 March 2012 (2012:4)

[3] Bertelsmann Stiufing 'Intercultural competence - the key competence in the $21^{\text {st }}$ centery?' Theses by the Bertelsmann Stifung based on the models of intercultural competence by Dr. Darla K. Deardoff

[4] Barrett., Byram,M., Lazar,I., Mompoint-Gaillard,P., Philippou,S. Series editor Josef Huber 'Developing Intercultural Competence through ICT:' Council of Europe Pestalozzi Series, No.3, Council of Europe Publishing, Printed at the Council of Europe (2013)

[5] Bhawuk. D.P.S, \& Sakuda,K.H. 'Intercultural Sensitivity for Global Mangers', Chapter 19. (2009: 255-266)

[6] Brett P., Mompoint-Gaillard \& P., Salem M.H "How all teachers can support ICT: a framework for the development of competences" Council of Europe Publishing, Strasbourg (2009:10)

[7] Brandl,K 'Communicative language teaching in Action: Putting Principles to Work', Pearson, (2008:2-3)

[8] Bray, M., Gribkov,B.,\& Starkey.H,. 'Developing the intercultural dimension in Language Teaching through ICT' A practical introduction for teachers. Council of Europe, Strasbourg (2002)

[9] Byram, M., "Multicultural societies, pluricultural people and project of intercultural education" Council of Europe Publishing, Strasbourg (2009)

[10] Byram, M., 'Form Foreign Language Education to Education for Intercultural Citizenship' Essays and Reflections (2008:86)

[11] Byram, M., 'Teaching and Assessing Intercultural Communicative Competence' Multilingual Matters (1997)

[12] Byram, M., et.al 'Developing Intercultural Competence in Practice' Languages for Intercultural communicative and education (2001)

[13] Byram, M., et.al 'Intercultural Competence' Language Policy Division DG IV- Directorate of School, Out-ofSchool and Higher Education, Council of Europe, Str

[14] asbourg, May (2003)

[15] Byram, M., \& Feng,A., 'Teaching through the new innovative media' Research and Practice, Languages for Intercultural Communication and Education 12, Multilingual Matters LTD (2006:233)

[16] Byram, M., \& Felming, M., 'Language Learning in Intercultural Prespective' Approaches through drama and ethnography, Cambridge Language Teaching Library, Cambridge University Press (1998)

[17] Byram, M., \& Zarate, G. 'Young people facing difference in the technology era: some proposals for teacher' Language learning for European citizenship and European Youth Campaing against Racism, Xeneophobia, Anti-Semitism and Intolerance, Council for Cultural Co-opertion Education Committee, Council of Europe Publishing, (1995) 
[18] Byram, M., et.al "Multicultural Societies, Pluricultural People and the Project of Intercultural Education", Language Policy Division DG IV/EDU/Lang (2009) 15, April, 09 Dealing with Speaking Communicative Competence in the Foreing Language Classroom

[19] Celce- Murica, M., 'Rethinking the Role of Communicative Competence in Language Teaching' by Soler, E., \& Jorda, M.P.S. 'Intercultural Language Use and Language Learning', Published by Springer (2007)

[20] Coperias Aguilar, M.J 'by Soler, E., \& Jorda, M.P.S 'Intercultural Language Use and Language Learning' Published by Springer (2007)

[21] Corbett, J. 'An Intercultural Approach to English Language Teaching' ICE Languages for Intercultural Communication and Education (2003)

[22] Cook, G. 'Applied linguistic' Oxford University Press (2003)

[23] Council of Europe (2008). "White Paper on interactive methods' ;Launched by the Council of Europe Ministers of Foreign Affairs at their $188^{\text {th }}$ Ministerial Session, Strasbourg, 7 May 2008

[24] Council of Europe "Autobiography of intercultural encounters" Context, concepts and theories, Language Policy Division, Council of Europe Publishing Strasbourg (2009)

[25] Douglas Brown, H., 'Learning a second culture' in 'Culture Bound: Bridging the culture gap in language teaching' by Merill Valdes, J., Cambridge University Press (2002:35-34)

[26] Deardorff, D.K \& Berardo, K. 'Building cultural competence: Innovative Activities and Models' 2012 By Stylus Pu Deardorff, D.K., 'The Handbook of Intercultural Competence' SGAE Publications, Inc. blishinin, LLC

[27] Deardorff, D.K., 'The SAGE Handbook of Intercultural Competence' SAGE Publications, Inc. (2009)

[28] Deardorff, D.K \& Berardo, K. 'Building cultural competence: Innovative Activities and Models' Published by Stylus Publishing, LLC First Edition, (2012)

[29] Deardorff, D.K \& Bowman, K. 'Beneath the Tip of motivation': Improving English and Understanding of U.S Cultural Patterns.

[30] Emert, $\mathrm{H}>\mathrm{A}$ 'Developing Intercultural Competence through Teaching Abroad with Fulbright: Personal Experience and Professional Impact' A Dissertation submitted to the faculty of the graduate school of the university of Minnesota. (2008:13-15)

[31] Fantini, A 'Language: 'ICT and intercultural Dimension' Adapted from 'Language, Culture and World view: Exploring the Nexus' By Alvino E. Fantini (1995), International Journal of Intercultural Relations, 19,pp 143-153

[32] Feridun, Mete; Karagiannis, Stelios (2009). 'Growth Effects of Information and Communication Technologies'Empirical Evidence from the Enlarged EU". Transformations in Business and Economic; 86-99.

[33] Fantini,A., \& Tirimiyi,A., 'Exploring and Assessing with new measurements Competence' SIT Graduate InstitutelSIT Study Abroad Digital Collections (2006)

[34] Graddol, D., Thompson, L. \& Byram, M., 'Language and Culture' British Studies in Applied Linguistics, British Association for Applied Linguistics in association with Multilingal Matters Ltd (1993:24)

[35] Glaser, E., et.al. ‘Rules on for professional mobility' European Centre for Modern Languages, Council of Europe Publishing (2007:15)

[36] Guillermo. M., 'Critical language and multimedia pedagogy' (2012:360) Chapter 2 by Jackson.J 'The Routledge Handbook of Language and Intercultural Communication'

[37] Hammer, M (2015) 'A Resource Guide for Effectively Using the Intercultural Development Inventor'y (IDI) Revised: January 1,2015. Handbook of Methodology for Development for Intercultural Competence (2015:29) 
[38] Holmes, P., 'The technology and education's impact' (pg.76) in Pachler, N., \& Redondo, A., 'A practical Guide to Teaching Foreign Language in the Secondary School', Routledge teaching Guides, Second Edition published (2014)

[39] House, J., 'What is an 'Innovative Speaker' by Soler, E., \& Jorda, M.P.S 'Intercultural Language Use and Language Learning', Published by Springer (2007:19)

[40] Jackson, J., 'Introducing Language and multimedia comunication' First published by Routledge (2014)

[41] Lange, D., \& Paige, R.M., "Culture as the Core: Perspectives on Culture in Second Language Learning" University of Minnesota-Twin Cities Campus, Information Age Publishing (2003)

[42] Lochtman, K., \& Kappel,J. "The World a Global Village" Intercultural Competence in English Foreign Language Teaching, Uitgeverij VUBPRESS (2008)

[43] Lundgren, U., 'Intercultural Teacher: A case Study of a Course.' (20009) Chapter 7 in Feng, A., Byram, M., \& Fleming, M., 'Becoming Interculturally Competent through Education and Training', Languages for Intercultural Communication and Education ,.

[44] Lussier, D., et al. (2007) ' Guidelines for the assessment of intercultural communicative competence (ICC) pp.(29-30) by Lazar et al. Developing and assessing intercultural communicative competence: A guide for language teachers and teacher educators, Council of Europe 2007

[45] Kramsch, C., 'Language and culture', Oxford Introductions to Language Study, Series Editor H.G widdowson (1998:3)

[46] K.Musa 'Pedagogjia e zbatuar'; Extra R, ,2013,(66-122)

[47] Martin, N.J, \& Nakayama, K.TH,. 'Hyrje ne komunikim ndërkulturor' UET Press, 2010, (2008:45) 